\title{
Dorota Górska
}

The Pontifical University of John Paul II in Krakow, Poland

\section{E-learning in Higher Education}

\begin{abstract}
The vast use of the Internet and the increasingly widespread access to the latest technologies have become the main reason for the development of remote teaching services. In an effort to modernize the educational offer, higher education institutions placed, in their programs of studies, different possibilities of teaching using „distance learning”. This trend is already very common in the world's largest universities. The Polish higher education system, keeping the pace with current trends, has created a legal foundation for the use of modern forms of teaching. The current approach to teaching is also a response to the offer of leading universities of the world and thus the search for competitive advantage in the international educational market. The aim of the article is to present main objectives of the teaching method of e-learning, and at the same time, to present the legal status and the rules for the use of e-learning in Polish higher education. The article is based on the experience of such teaching introduced at the Pontifical University of John Paul II in Krakow.
\end{abstract}

\section{Keywords}

e-learning, remote teaching, Moodle, learning platform, online teaching. 
“...The changing world requires from universities a new way of thinking about studying: combining classes of various disciplines, teaching through modern technologies, e-learning, involving managers of economy...".

\section{Detailed regulations concerning conducting classes in the form of e-learning}

Teaching in the form of e-learning is a modern supplement, and sometimes even an alternative to traditional education. It allows learning at a very high level, available anywhere and at any time. The use of a specially prepared original teaching material such as syllabi, lectures, interactive exercises, instructional videos, and many other multimedia contents that make distance learning, become effective and are also in line with expectations of students. Noteworthy is the fact that a new form of education allows for virtually immediate verification of knowledge.

This method, due to its characteristics, allows to carry out activities in a twofold form. „Distance learning” (distance education) is the education that excludes the physical presence of the teacher. The source of the material to study and examiner is in fact a computer connected to the Internet. The second way is „blended learning”. E-learning is used here only as a tool to support the teaching process. In parallel with the electronic form of communication, classes are held in the traditional way, with the physical presence of teachers and students. ${ }^{2}$

E-learning allows a manual selection the preferred format for the delivery of knowledge and its transmission rate. The most advanced, yet easiest technology to use and implement is the educational platform capable of conducting e-learning classes. A platform for distance learning is the professional Internet service with teaching profile. The platform creates a separate Web page, on training materials are placed. Access to the site is password protected and requires the login ID as well as given individual password. Platforms allow

${ }^{1}$ L. Kolarska-Bobińska Komentarz Minister Nauki i Szkolnictwa Wyższego do nowej ustawy o szkolnictwie wyższym, 24 lipca 2014, http://www.nauka.gov.pl/aktualnosci-ministerstwo/ parlament-przyjal-nowa-ustawe-o-szkolnictwie-wyzszym.html (23.03.2016).

${ }^{2}$ M. Plebańska, I. Kula, E-learning: treści, narzędzia, praktyka, Warszawa 2011, Almamer. 
delivering classes on-line and remote support for students. With powerful capabilities and the ease of service, using the platform, the use of the platform gives a great potential to further education and to promote science. ${ }^{3}$

E-learning in Poland offers to students and teachers a variety of learning opportunities and mutual communication. It changed the learning environment too. This happened with the approval and with the support of the Ministry of Science and Higher Education, which, for many years now, recognizes the need to integrate ICT in education.

The first legislation authorizing such kind of classes with methods and techniques of distance learning at the universities was introduced by the Act of 27 July 2005 - Law on Higher Education Article. 164, $\$ 3$. At the same time, the same law obliged the „minister responsible for higher education to determine by regulation, the conditions that must be met in order for classes to be conducted, ensuring proper accessibility for students of classes conducted using the methods and techniques of distance learning and an appropriate proportion of time of these classes, respectively for full-time and part-time studies, with the total time classes at the university".

Currently, rules for the application of e-learning at the universities have been standardized by the Regulation of the Minister of Science and Higher Education of 25 September 2007, as amended on 2 November 2011. This regulation includes the conditions that must be met during the studies at universities which use distance learning methods and techniques.

According to the decree the number of hours of lectures and exercises on a full-time and part-time studies using e-learning can not be greater than $60 \%$ of the total number of hours of specific training programs for individual fields of study and levels of education. Institutions offering classes must meet all of the following conditions:

- have a staff of academics prepared to teach classes using methods and techniques of distance learning;

- provide an access to infrastructure and software that enable synchronous and asynchronous interaction between students and academic staff;

- provide educational materials developed in electronic form;

${ }^{3}$ K. Kuźmicz, E-learning: kultura studiowania w przestrzeni sieci, Sopot 2015, Gdańskie Wydawnictwo Psychologiczne.

${ }^{4}$ Prawo o szkolnictwie wyższym, ustawa z dnia 27 lipca 2005 r. (Dz.U. nr 164, poz.1365, z późn. zm.). 
- provide to each student the opportunity of personal consultation with the teacher at the university;

- provide ongoing monitoring of the academic progress of students, the verification of knowledge and skills, including exams at the end of classes;

- ensure the ongoing monitoring of the activity of the teachers. ${ }^{5}$

Teaching material placed in the network, related to e-education and e-learning technology in higher education, are protected by the Act of 4 February 1994 on Copyright and Related Rights (Dziennik Ustaw, 2000, n. 80, item. 904 with amendments). According to this law any manifestation of creative activity of an individual, recorded in any form, regardless of the value, purpose, and manner of expression shall be subject to copyright. Thus the work will automatically be subject to legal protection from the moment of its creation (they are eg.: the texts published in the Internet, movies, music recordings, computer programs). Copyright-protected are also databases with features of works (even if these materials are not protected by copyright). The works classified in this category must meet the criteria of originality, eg.: in the selection of materials or developed structure. They talk about the provisions in the Dziennik Ustaw, 2006 No. 90, item. 631, No. 94, item. 658, No. 121, item. 843 and Dziennik Ustaw, 2007 No. 99, item. 662.

Under protection are also databases included in the network that are not works (such bases are understood as a set of any materials and components assembled according to a specific systematics or method available in any way, including those created by electronic means, if their creation required a significant financial effort or work). It is regulated by the Act of 27 July 2001 on the protection of databases (Dziennik Ustaw, 2001, n. 128, pos. 140262$)^{6}$

The content posted on the network is also protected by the Act of 18 July 2002 on electronic services (Dziennik Ustaw, 2002, n. 144, item. 1204), in the

${ }^{5}$ Rozporządzenie Ministra Nauki i Szkolnictwa Wyższego w sprawie warunków, jakie muszą być spełnione, aby zajęcia dydaktyczne na studiach mogły być prowadzone z wykorzystaniem metod i technik kształcenia na odległość z dnia 25 września 2007 r. (Dz.U. Nr 188, poz. 1347), Rozporządzenie Ministra Nauki i Szkolnictwa Wyższego zmieniające rozporządzenie w sprawie warunków, jakie muszą być spełnione, aby zajęcia dydaktyczne na studiach mogły być prowadzone z wykorzystaniem metod i technik kształcenia na odległość z dnia z dnia 2 listopada 2011 r. (Dz. U. nr 246, poz. 1470).

${ }^{6}$ P. Waglowski, Ochrona baz danych, Warszawa 2009, wyd. Polska Agencja Rozwoju Przedsiębiorczości. 
amendment of 7 October 2013. This law defines the principles of responsibility and obligations of service providers affording electronically supplied utilities, as well as the principles of protection of individuals' personal data.

Another law governing the protection of teaching materials posted on the Web is the Act of 16 April 1993 on combating unfair competition (Dziennik Ustaw, 2003, n. 153, pos. 1503), which protects against illegal activities or morality. ${ }^{7}$

All the above regulations also apply in relation to e-learning courses. By 'work' it is intended not only the entire course offered via e-learning, but also its individual elements. Developers are entitled to the full range of authors' rights, but property rights are entitled to, in most cases, universities employing teachers - authors of courses. ${ }^{8}$

\section{Adaptation of the methods of distance learning to the requirements of the Ministry, based on the analysis of the conduct of such activities at the Pontifical University of John Paul II in Krakow}

Pontifical University of John Paul II has participated in the e-learning system since the beginning of the academic year 2009/2010.

Classes are conducted at the Pontifical University of John Paul II in accordance with the Regulation of the Minister of Science and Higher Education on the conditions that must be met for classes at the universities which use the methods and techniques of distance education. On the 23 September 2013, at a meeting of the Senate of university, the „Regulations on the use of e-learning platform of the University of John Paul II in Krakow" were approved. According to the provisions contained in the rules of the University the formula of "blended learning was introduced using the platform to support the activities carried out in the traditional manner. The number of hours of classes with methods and techniques of distance learning can not exceed $40 \%$ of the total number of hours

${ }^{7}$ K. Chrabąszcz, Wykorzystanie e-learningu w procesie kształcenia studentów, „Zeszyty Naukowe MWSE w Tarnowie" 1 (2011), p. 55-66.

${ }^{8}$ D. Górska, E-learning jako narzędzie wspomagające proces uczenia, „Forum Bibliotek Medycznych" 7 (2014) 2, p. 303-318. 
of classes. Every hour of lecture conducted by way of e-learning is equivalent to 1.5 hours of classical teaching. ${ }^{9}$

The Pontifical University of John Paul II (UPJPII) respects the fundamental conditions to be met by the university in order that classes can be carried out using the methods and techniques of distance education. The method of distance learning can be used at the university in all fields of study and levels of education, both in the stationary and non-stationary mode of study.

- The University provides the teaching staff with an adequate preparation to facilitate the teaching by methods and techniques of distance learning.

The condition for opening an e-learning course at UPJPII is the participation of an academic teacher in training in the basics of remote learning and use of its platform. Lecturers, after providing them with a login and password, can start use the platform. At the beginning of each semester qualified CYFRONET (Academic Computer Center in Cracow) staff offer training for volunteers, explaining rules for the use of the platform and placing of the teaching materials on it. During the training, teachers learn the principles of creating and running e-courses, as well as full management of ongoing courses, tracking the progress of participants and monitoring the entire educational process. Researchers conducting the classes using method of e-learning have beenprovided with the support of specialists of information and communication technologies, since the first years of use of the e-learning. The University based its activity on the services offered by CYFRONET.

According to the agreement, CYFRONET provided a full time service, administration and support in the organization of the courses on Moodle platform, to result in stability and reliability. In the case of need and help, the support of qualified staff is offered. ${ }^{10}$

- UPJPII provides access to infrastructure and software that enable synchronous and asynchronous interaction between students and academic staff.

Adequate infrastructure and software provide the basis for the implementation and application of distance learning. In the years 2009-2015 the university has

${ }^{9}$ Regulamin korzystania $z$ platformy e-learningowej na Uniwersytecie Jana Pawła II w Krakowie, http://upjp2.edu.pl/?q=e-nauczanie/regulamin-korzystania-z-platformy-elearningowej-na-upjpii (23.03.2016).

10 D. Górska, R. Mazur, E-learning na Uniwersytecie Papieskim Jana Pawła II w Krakowie, „Vita Academica” (2016) 1, Wydawnictwo Naukowe Uniwersytetu Papieskiego Jana Pawła II w Krakowie, p. 15-16. 
used the online education system platform based on Blackboard, equipped with tools for creating and managing learning content. From 25 September 2015 UPJPII offers remote education, based on an open platform e-learning Moodle platform (Modular Object-Oriented Dynamic Learning Environment). Moodle is an IT system for the management and organization of distance learning. It has a simple and effective interface for web browsers that allows easy viewing of the contents of the course. Users can take full advantage of all the features of the platform without having to install additional software. The platform is equipped with modules that enable collaboration at the levels student-student and studentteacher. Platform Moodle allows both asynchronous and synchronous contact between students and teachers. Asynchronous teaching method gives the opportunity to learn without personal contact with the lecturer (contact only by e-mail or on a forum). The advantage of asynchronous learning is the possibility of an individualized pace, place and intensity of learning. Synchronous learning is characterized by the exchange of information and communication in real time. Participants and teachers interact via chat or video conference „live”, that is, at a specified time. The online course is characterized by a multilateral exchange of information and communication in a predetermined time interval ${ }^{11}$.

- Taking care of the teaching materials developed in electronic form.

Accordingly to the ministerial regulation, the university needs to provide educational materials, developed in electronic form. On the platform one can find copyrighted university teaching resources. Arrangement of courses available on the platform allows enrichment of posted teaching materials especially with prepared charts, diagrams, sound files, videos, animations, interactive exercises and many other multimedia materials. The whole educational content is available to students enrolled in courses.

- The students are also provided with the opportunity of personal consultation with the teacher at university. UPJPII provides the possibility of personal meetings with lecturers. When deciding on the introduction of „blended learning”, UPJPII used the platform only to supplement and enrich the activities conducted in the traditional manner. According to the regulations, $60 \%$ of lessons are conducted at the university. Most of the classes, consultations and all final exams at UPJP II are held in the lecture halls of the university.

11 A. Majkiewicz, T. Walasek, Moodle - narzędziem edukacyjnym XXI wieku, Częstochowa 2011, Wydawnictwo Wyższej Szkoły Lingwistycznej. 
- Ongoing monitoring of the academic progress of students, verification of knowledge and skills include the mid-year and final exams.

The adopted form of learning combines the advantages of the remote and the traditional study and has a high efficiency of education. Posted teaching materials serve to broaden the knowledge presented during lectures. Taking advantages offered on Moodle platform, teachers can monitor the progress of students, and through verification tests can check the level of knowledge they have acquired. The University therefore provides constant control of students' progress in learning. The teachers check progress of students through tests of multi- or single-choice quizzes or scientific evaluation surveys. Teachers can survey the students' work on the platform, e.g. by prepared statistics of active interaction with the platform. Lecturers also have the possibility to limit access time to the placed content, as well as the strict determination of the number of scrolls of a specific page. All final exams are held at the university.

- Monitoring the activity of teachers.

It checked the compatibility of activities of the program requirements of a given field of study.The didactic base necessary for the implementation of the curriculum is evaluated (e.g. syllabus adaptation to the required effects, goals and methods of teaching, control of the content of teaching materials). The realization of the goals of teaching and learning outcomes achieved by students is subjected to thorough analysis as well, characterizing the specified area included in the National Qualifications Framework for Higher Education.

The „mixed teaching method", offered to the students of UPJPII, gives the possibility to supplement the knowledge acquired during the traditional classes with the use of educational materials placed on the platform. Efficient use of the platform does not require a special training of students, because the students receive Moodle 2.9+ as a web page. Only the access to the platform requires a short introduction, because it is protected with login and asks for individual password. Regarding users with a lower level of technological competence, it offers regular assistance from the staff involved in the organization of work on the platform.

\section{Conclusion}

E-learning brings a new quality to academic education. Following the most prestigious academic centers worldwide, many Polish universities have decided to offer lecturers the wide use of methods and techniques of distance learning. 
The openness of the universities to the introduction of a variety of learning and teaching methods using an interactive method of communication is a response to the expectations of the young generation of nowadays. Access to advanced technologies is very highly valued by young people accustomed to the daily use of electronic media. Many high school students approaching the future studies at the university are guided by the possibility to follow courses offered not only with traditional methods. With no need of personal attendance in all lectures there isa decrease in the cost of education and the possibility of flexible participation in the classes. E-learning is seen by young people as an attractive and modern form of learning. In its assumptions learning using the Internet allows overcoming educational barriers. ${ }^{12}$ E-learning increases the efficiency of the educational process and changes the way people learn. It helps to broaden the experience of students and provides tools that allow the use of newest technologies.

Noting the dynamics of the use of methods and techniques of distance learning at Polish universities, it is clear that e-learning - while maintaining an adequate quality of education - is an important tool for supporting or even replacing traditional teaching methods.

\section{Bibliography}

Chrabąszcz K., Wykorzystanie e-learningu w procesie kształcenia studentów, „Zeszyty Naukowe MWSE w Tarnowie" 1 (2011), p. 55-66.

Górska D., E-learning jako narzędzie wspomagajace proces uczenia, „Forum Bibliotek Medycznych" 7 (2014) 2, p. 303-318.

Górska D., R. Mazur, E-learning na Uniwersytecie Papieskim Jana Pawła II w Krakowie, „Vita Academica” (2016) 1, Wydawnictwo Naukowe Uniwersytetu Papieskiego Jana Pawła II w Krakowie, p. 15-16.

Kuźmicz K., E-learning: kultura studiowania w przestrzeni sieci, Sopot 2015, Gdańskie Wydawnictwo Psychologiczne.

Majkiewicz A., Walasek T., Moodle - narzędziem edukacyjnym XXI wieku, Częstochowa 2011, Wydawnictwo Wyższej Szkoły Lingwistycznej.

Plebańska M., Kula I., E-learning: treści, narzędzia, praktyka, Warszawa 2011, Almamer. Waglowski P., Ochrona baz danych, Warszawa 2009, wyd. Polska Agencja Rozwoju Przedsiębiorczości.

12 D. Górska, E-learning jako narzędzie wspomagajace proces uczenia, „Forum Bibliotek Medycznych" 7 (2014) 2, p. 303-318. 